\title{
Taxonomic entities of two Korean plant taxa: Vicia bifolia (Fabaceae) and Cyperus compressus (Cyperaceae)
}

\author{
Seung Se CHOI, Jonghwan KIM ${ }^{1^{*}}$, Myoung Jun Kim² and Chul Hwan KIM ${ }^{3 * \dagger}$ \\ Team of National Ecosystem Survey, National Institute of Ecology, Seocheon 33657, Korea \\ ${ }^{1}$ Sung-ho Green Tech, Jangseong 57248, Korea \\ ${ }^{2}$ Botanic Garden Yeomiji, Seogwipo 63535, Korea \\ ${ }^{3}$ The Korean Association for Survey \& Assessment of Ecosystem, Anyang 14059, Korea \\ (Received 19 November 2021; Revised 20 December 2021; Accepted 27 December 2021)
}

\begin{abstract}
Vicia bifolia Nakai (Fabaceae) and Cyperus compressus L. (Cyperaceae) have been ambiguous in terms of their distribution and taxonomic entities in Korea. The existence of these two taxa was confirmed when V. bifolia and C. compressus was found on Jellabuk-do, Gyeongsangnam-do, and Jeju-do. Vicia bifolia is similar to $V$. unijuga by having a pair of leaflets but is distinguished by the length of the petiole, the size and degree of longevity of the bracts, and the shape of the stipules. Cyperus compressus was found on Jeju-do, is similar to $C$. tenuispica, C. haspan, and C. flaccidus, but is distinguished by the branching pattern of the inflorescences and the size of scales and achenes. A description, differences from related species, a key to the taxa and photographs of Korean Vicia bifolia and Cyperus compressus are provided in this study.
\end{abstract}

Keywords: Cyperus compressus, distribution, Korea, taxonomic entity, Vicia bifolia

Two taxa are known to be distributed in Korea according to several studies in the literature, but their distribution and taxonomic entities have not been confirmed thus far. These are Vicia bifolia Nakai (Fabaceae) in the southern region and Cyperus compressus L. (Cyperaceae) on Jejudo Island in Korea.

The genus Vicia L., which consists of 140-160 taxa, is known to be distributed mainly in the Northern Hemisphere (Bao and Tur, 2010; Choi, 2018), and approximately 17 taxa are distributed in Korea (Choi, 2018). This genus is distinguished from other genera in the family, such as Lathyrus L., by the following morphological characteristics. Most of these have two or more pairs of paripinnately compound leaves, entire leaflet margins, tendrils or mucronate tips at the apices of the leaf axes, diadelphous $(9+1)$ stamens, staminal tubes oblique at the apices, and terete styles. Also, at maturity, the legumes are dehiscent along the sutures, with two to eight seeds (Bao and Tur, 2010; Choi, 2018). Among Korean Vicia, taxa composed of one pair of leaflets similar to $V$. bifolia include $V$. unijuga and several varieties that are also considered to be synonyms for $V$. unijuga depending on the author; specifically, V. unijuga var. apoda Maxim., V. unijuga var. angustifolia Nakai, V. unijuga var. breviramea Nakai, $V$. unijuga var. integristipula H. Lev., V. unijuga var. kaussanensis H. Lev., V. unijuga var. ohwiana (Hosok.) Nakai, V. unijuga var. ouensanensis H. Lev., and V. unijuga var. venusta Nakai are known (Nakai, 1952).

Meanwhile, Korean $V$. bifolia was recorded for the first time in Korea by Nakai (1952), with Park (1974) later agreeing with this view, mentioning that it was distributed in central Korea. Also, Lee (1996) recorded the distribution area of this species as "Korea (?) and Japan." Most major domestic studies in the literature (Chung, 1957; Lee, 1980; Choi, 2007, 2018), including several monographic studies related to $V$. unijuga (Yim, 1983; Seok and Choi, 1997; Han et al., 2021), do not mention this species at all. Therefore, the distribution in Korea and the entity of this species are currently unclear. Interestingly, it was mentioned in a publication on the flora of the Korean Peninsula published in Pyeongyang (Im, 1998) that this species grows in the southern region of Korea. It is also recorded in

\footnotetext{
Deceased.

*Author for correspondence: plantaxa@hanmail.net (C. H. Kim), sukoook@empass.com (J. Kim)
} 
the Japanese literature (Ohwi, 1984).

The genus Cyperus L. is widely distributed throughout the temperate and subtropical tropical regions, with as few as 670 species (Dai et al., 2010) and as many as 810 species worldwide (Govaerts and Simpson, 2007), including Pycreus P. Beauv., which is sometimes treated as a separate genus depending on the author, and is known to be distributed in 18-21 taxa in Korea (Cho et al., 2016; Oh, 2018). Cyperus s.l. is morphologically composed of taxa with many bisexual flowers per spikelet, without perianths, generally with compressed scales arranged in two rows, and the style bases are continuous with ovaries, meaning that the bases are not particularly swollen (Kern, 1974).

Among plants distributed in Korea, depending on the author, taxa with two stigmas and the angular part of the achene facing the spikelet axis (rachillae) are classified as belonging to the genus Pycreus (Govaerts and Simpson, 2007; Dai et al., 2010; Takuji et al., 2011). Also, taxa with the angular part of the achene facing the spikelet axis and with one spikelet consisting of one to two bisexual types and one to two scales are classified as belonging to the genus Kyllinga (Tucker et al., 2002; Govaerts and Simpson, 2007; Dai et al., 2010; Hoshino et al., 2011; Oh, 2018).

On the other hand, Korean C. compressus has not been mentioned in major domestic studies in the literature (Chung, 1957; Lee, 1980; Lee, 1996; Oh, 2000; Cho et al., 2016; Oh, 2018) thus far since Park (1949) presented the scientific and Korean name in the Korean botanical name catalog.

However, as these two taxa were recently collected from the southern region of Korea through a national survey of the natural environment, this study intends to reveal their domestic distribution and taxonomic entities.

\section{Materials and Methods}

The field surveys were carried out on 17 July 2019 and 26 July 2020 in Mt. Moaksan, on 16 July 2020 on Mt. Sutaesan for $V$. bifolia, and on 17 October 2020 on Jejudo Island for $C$. compressus. Specimens were examined using a stereomicroscope (Nikon SMZ445). Photographs were taken using Nikon D850 and Canon 60D cameras. The nomenclature, classification, and Korean name basically follow the conventions of the National Institute of Biological Resources (2019). Voucher specimens are deposited in the herbarium of the National Institute of Ecology (NIE).

\section{Taxonomic Treatment}

1. Vicia bifolia Nakai, Bot. Mag. (Tokyo) 37: 15, 1923 (Fig.
1).-TYPE: JAPAN. Honshu, Nikko, 29 Jul 29 1877, J. Matsumura s.n. (Syntype: TI!); Mt. Nikko, in the mountain ( 山內), 10 Jun 1910, S. Komatsu S.n. (Syntype: TI!).

Vicia fauriei var. unijuga Matsum., Bot. Mag. (Tokyo) 16: 81, 1902.

Vicia unijuga var. bracteata Franch. \& Sav., Enum. Pl. Jap. 2: 325, 1878; Vicia bracteata (Franch. \& Sav.) Koidz., Fl. Symb. Orient.-Asiat. 25, 1930.

Korean name: 잔나비나물 (Jan-na-bi-na-mul, Park, 1974).

Perennial herbs, $30-80 \mathrm{~cm}$ tall. Stems ascending to erect, angled, zigzagged and sometimes branched above the middle. Leaves alternate, 1-paired paripinnate; stipules lanceolate to broadly ovate, $10.0-20.0 \times 5.0-12.0 \mathrm{~mm}$, asymmetric at bases, subentire or nearly so at margins; petioles nearly sessile to ca. $3 \mathrm{~mm}$ long; rachises with linear bristles at apices, ca. $3 \mathrm{~mm}$ long; leaflet blades 8-14 × 4-8 cm, lanceolate to broadly ovate, asymmetric at bases, entire and undulate sometimes 1-2 incised at margins, acuminate or acute at apices, sparsely hairy on both surfaces nearly so. Inflorescences in axillary racemes, 1 sometimes 2, ca. $4 \mathrm{~cm}$ long, much shorter than leaves; peduncles nearly sessile to ca. $3 \mathrm{~mm}$ long; bracts 1 at each base of flowers, $3.5-10.0 \times 2.0-4.0 \mathrm{~mm}$, lanceolate to ovate, subentire sometimes serrate at margins, persistent; pedicels ca. $2 \mathrm{~mm}$ long. Flowers zygomorphic and papilionaceous, 15-20 at each inflorescence, ca. $1.5 \mathrm{~cm}$ long. Calyces $4.5-5.5 \mathrm{~mm}$ long, obliquely tubular with 5 short teeth; teeth ca. $1 \mathrm{~mm}$ long. Corollas pale reddish purple; standards obovate, emarginate at apices; wings slightly shorter than standard and longer than keels. Stamens diadelphous, 9+1; staminal tubes oblique at apices. Ovaries glabrous; styles hairy above the middle. Legumes compressed, oblong, ca. $3 \mathrm{~mm}$ long. Seeds 2-4.

Flowering: July-September.

Habitat: It grows in small populations in shady forests in mountainous areas. Thus far, only two populations have been identified in both regions, and the number of individuals amounts to only a few dozen.

Distribution: Japan (Honshu), Korea (southern region including Jeollabuk-do and Gyeongsangnam-do).

Specimens examined: KOREA. Jeollabuk-do: Wanju-gun, Gui-myeon, Mt. Moaksan, 17 Jul 2019, C. H. Kim s.n (6 sheets, JNU); Wanju-gun, Gui-myeon, Mt. Moaksan, 26 Jul 2020, $C$. H. Kim s.n (3 sheets, JNU); Gyeongsangnam-do: Goseonggun, roadside at the foot of the mountain between Mt. Sutaesan and Mt. Hyangrobong, 16 Jul 2020, C. H. Kim \& S. S. Choi s.n (9 sheets, JNU).

Viola bifolia was published as a new species by Nakai (1923) based on a specimen collected by J. Matsumura on July 29, 


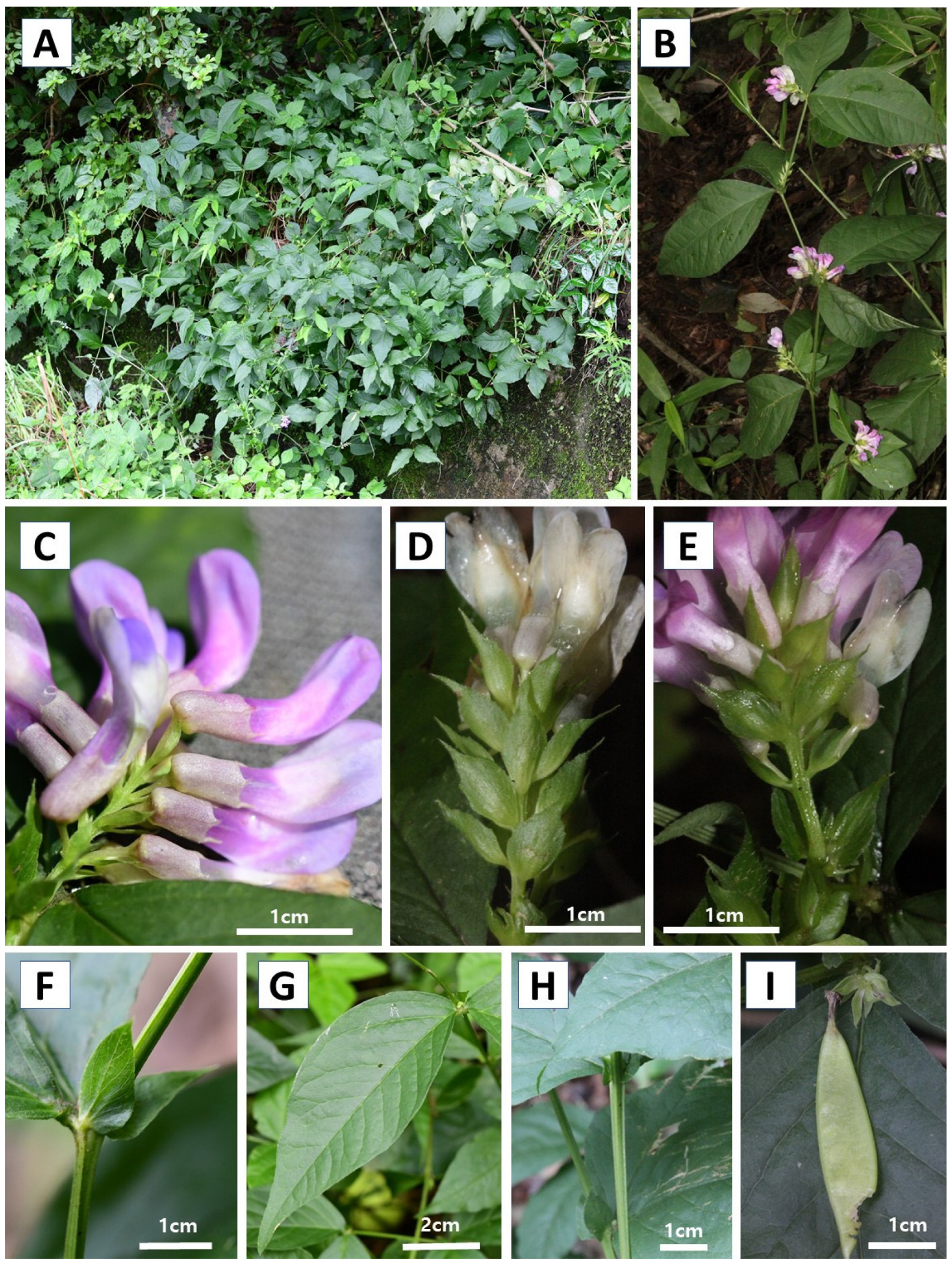

Fig. 1. Vicia bifolia. A. Habitat, B. Flowering plant. C-E. Flowers with bracts. F. Stipules with leaves. G. Leaves. H. Stem with leaves. I. Legume. A, C, F, G Photographs were taken at Mt. Sutaesan by C. H. Kim and S. S. Choi, B, D, E, H, I Photographs were taken at Mt. Moaksan by C. H. Kim and S. S. Choi. 
1877 and a specimen from S. Komatsu on June 30, 1910 in Nikko, Honshu, Japan. Later he recorded this species as distributed in Korea (Nakai, 1952). Before Nakai (1923) recognized this species as a new species, Franchet and Savatier (1878) and Matsumura (1902) had already confirmed the existence of this taxon; these were published as varieties belonging to $V$. unijuga and $V$. fauriei Franchet, respectively. Therefore, if it is recognized at the variety level, V. unijuga var. bracteata Franch. \& Sav. would be the correct names for this taxon. With regard to these scientific names, studies focusing on nomenclatural and taxonomic synonyms based on type specimens are necessary.

Viola bifolia is an erect or ascending plant, and each node of the stem has a leaf composed of one pair of leaflets, with tendrils not developed at the apices of the leaf axes. Thus, this species is distinguished from most taxa in the genus, which develop tendrils at the apices of leaf rachises or are climbing plants such as $V$. amoena Fisch. It is also easily identified from the remaining taxa with leaves consisting of two or more pairs of leaflets, such as $V$. chosenensis Ohwi.

This species is most similar to $V$. unijuga and $V$. ohwiana Hosok. in that it has leaves composed of one pair of leaflets. However, this species has very short petioles often less than about $0.3 \mathrm{~cm}$ long, lanceolate, or ovate bracts reaching 0.4 $1.0 \mathrm{~cm}$ in length clearly developed, with bracts persisting in the fruiting stage. The two taxa mentioned above differ by having long petioles over $0.5-1.5 \mathrm{~cm}$ in length, having no bracts or those that are very small, approximately $1 \mathrm{~mm}$ in length, and that easily fall off. Random amplified polymorphic DNA data and an internal transcribed spacer sequencing analysis by Seok and Choi (1998) also revealed that Japanese $V$. bifolia was grouped with $V$. venosa var. cuspidata Maxim. and the vine $V$. japonica A. Gray, having three to seven pairs of leaves, as opposed to $V$. unijuga.

On the other hand, the Korean $V$. bifolia reaches a height of $80 \mathrm{~cm}$, leaflets are $8-4 \times 4-8 \mathrm{~cm}$ in size, and the number of flowers per inflorescence is approximately 15-20. In contrast, according to the type specimens at TI ( $J$. Matsumura s.n. and S. Komatsu s.n.) and one study in the literature (Maekawa et al., 1961), Japanese plants show a difference in that the plant heights are $30 \mathrm{~cm}$, the leaflets are 3.0-10.5 $\times$ $1.7-3.0 \mathrm{~cm}$ long, and the number of flowers per inflorescence is fewer with 6-10. However, this was judged as intraspecific variation in consideration of the fluctuation in the characteristics of $V$. unijuga, a similar species. In conclusion, Korean plants and Japanese plants are considered to be the same species according to the size of the petioles and the persistence of the bracts.
As a result, $V$. unijuga is widely distributed in the mountains of the Korea, and V. ohwiana as described by Hosokawa (1933) is distributed throughout the northern mountainous areas of the Korean Peninsula, Manchuria, and the Russian Far East. On the other hand, $V$. bifolia is expected to grow discontinuously in the southern mountainous areas of Korea, including Jeollabuk-do and Gyeongsangnam-do.

The Korean name Jan-na-bi-na-mul (Park, 1974) is expected to be made official in the sense that it is smaller than the $V$. unijuga; however, this species is not smaller than $V$. unijuga.

The key to the species is shown below; here, varieties and forma that are generally treated as the same species as $V$. unijuga or $V$. ohwiana are excluded. In addition, as pointed out by Kim and Park (2013), V. linearifolia, an illegitimate later homonym, is also excluded.

\section{Key to the Korean Vicia species with unijugate leaves}

1. Leaves with 1-paired leaflets at each node on stems.

2. Petioles nearly sessile to shorter than ca. $0.3 \mathrm{~cm}$ long; bracts ca $3.5-10.0 \times 2.0-4.0 \mathrm{~mm}$ in raceme inflorescences, distinct, lanceolate to ovate, persistent ……………......

\section{V. bifolia 잔나비나물}

2. Petioles ca. $0.5-1.5 \mathrm{~cm}$ or more in length; bracts absent or vestigial in raceme inflorescences, early deciduous.

3. Peduncles and rachises of racemes somewhat longer, easily visible rachises; calyx teeth shorter, straight, smooth and glabrous or nearly so at margins ……………………V. unijuga 나비나물

3. Peduncles and rachises of racemes shorter, sometimes capitate, nearly not visible rachises; calyx teeth much longer, often irregularly slightly curved, long and hairy at margins .....

V. ohwiana 함경나비나물

1. Leaves with at least 2-paired or more leaflets at each node on stems all other taxa of Korean Vicia

2. Cyperus compressus L., Sp. Pl. 1: 46, 1753 (Fig. 2).TYPE: "Americae septentrionalis pratis arenosis" (not seen); Chlorocyperus compressus (L.) Palla, Denkschr. Kaiserl. Akad. Wiss., Wien Math.-Naturwiss. K1. 84: 451, 1909.

Korean name: 개방동사니 (Gae-bang-dong-sa-ni, Park, 1949).

Annual herbs with fibrous roots and without rhizomes. Culms tufted, 5-30 cm tall, triquetrous, smooth, with leaves at bases. Leaves usually shorter than culms; sheaths purplish 

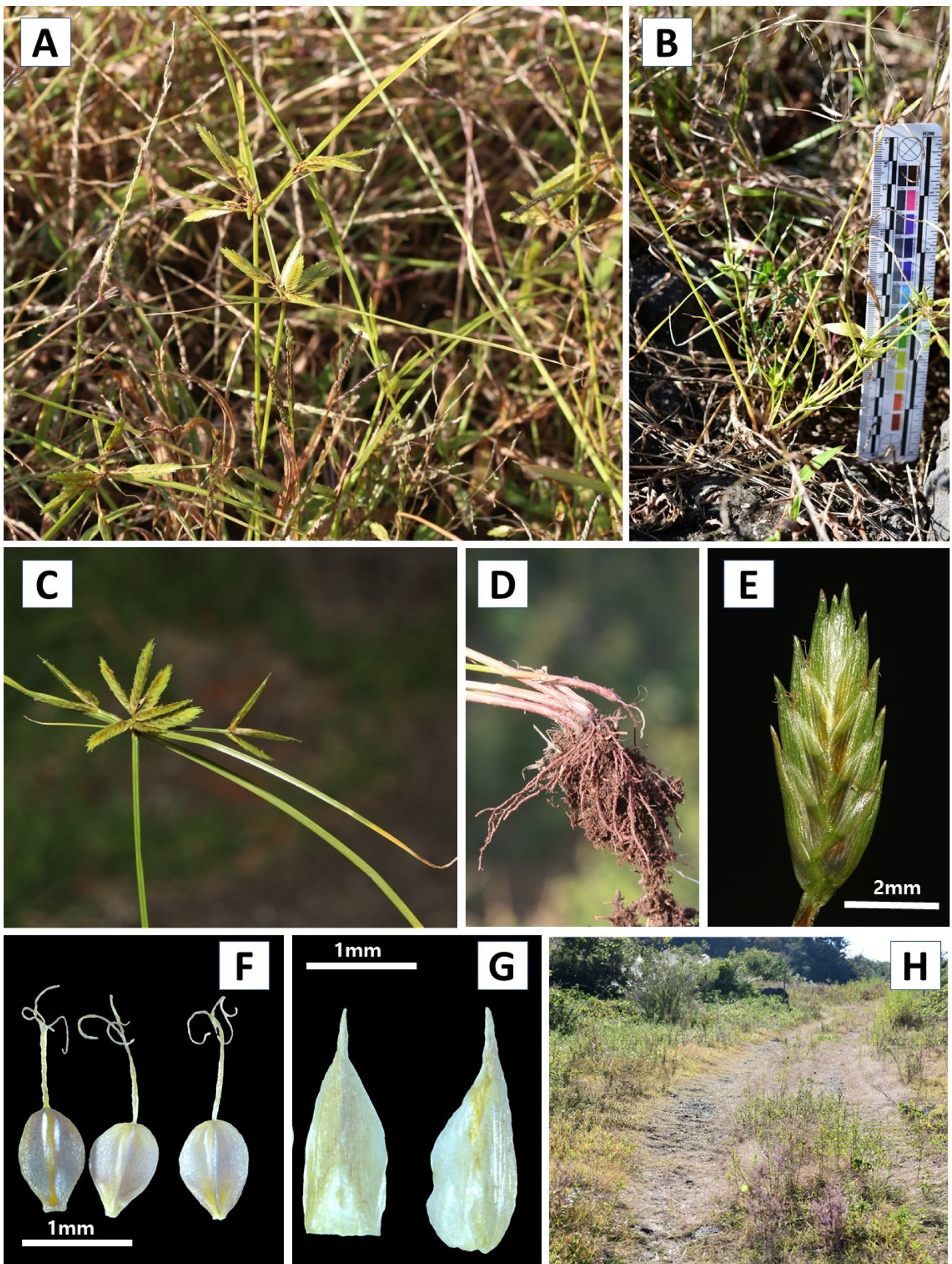

Fig. 2. Cyperus compressus. A, B. Habitat. C. Inflorescence having several spikelets. D. Roots. E. Spikelets. F. Achenes. G. Scales. H. Growing on the roadside around farmland. A-H Photographs were taken at Doneori-oreum by M. J. Kim and S. S. Choi. 
brown; blades 1-3 $\mathrm{mm}$ wide, flat, sometimes slightly plicate. Bracts 2-5, leaflike, unequal, longer than inflorescences. Inflorescences simple anthelae with primary branches, sometimes capitate; branches $0-5$, spreading or ascending, up to $5 \mathrm{~cm}$ long, each with 1 spike at the apice. Ultimate spikes digitate, with 3-10 spikes; rachises nearly absent or very short. Spikelets linear, $1.0-2.5 \times$ ca. $0.3-0.4 \mathrm{~cm}$, ascending to spreading or slightly reflexed, yellowish-green, distichously compressed, ca. 10-35 flowered; rachillae persistent, initially winged; wings white, very thinly and narrowly, caducous. Scales ovate, ca. 3.5 $\mathrm{mm}$ long, slightly reflexed short awns at apices, midveins thick, deciduous. Perianth absent. Styles ca. $1.2 \mathrm{~mm}$ long, slightly shorter than achenes; stigmas 3 . Anthers 3 . Achenes ca. $1.5 \times$ $1.0 \mathrm{~mm}, 1 / 2-1 / 3$ as long as scales, broadly obovoid, trigonous with 3 slightly concave sides, shining dark brown.

Flowering: August-October.

Habitat: Open and sunny grasslands in lowlands; hundreds of individuals are growing in groups within an area of about $50 \times 5 \mathrm{~m}$.

Distribution: Pantropical countries including those in Africa, Central and South America, and Asia; Korea (Jeju-do).

Specimens examined: KOREA. Jeju-do: Jeju city, grassy region, on sides of the volcano Doneori-oreum, 17 Oct 2020, S. S. Choi \& M. J. Kim s.n (3 sheets, JNU).

Cyperus compressus was declared as a new species based on specimens collected in the United States (Linnaeus, 1753). This species is known to be distributed throughout the tropical regions of Asia, Southeast Asia, Australia, Africa, Australia and South and Central America. Areas also include China and Japan, which are geographically adjacent to the Korean Peninsula. It is not found in Europe (Tucker et al., 2002; Dai et al., 2010).

Cyperus compressus in Korea is no different from unrecorded species since Park (1949) presented the scientific name and Korean name in the Korean botanical catalog; it has not been mentioned in related major domestic studies in the literature thus far. Its distribution and entity in Korea have not been confirmed

Cyperus compressus is similar to C. haspan, C. tenuispica, and $C$. flaccidus in that 3-10 spikelets stick to the end of spikes and rachises are nearly absent or very short. However, this species is characterized by simple inflorescence with primary branches; the scales and achenes are as long as $3.5 \mathrm{~mm}$ and $1.5 \mathrm{~mm}$ long, respectively. The remaining three taxa are distinguished in that the inflorescences are branched with 2-3 branches, and the scales and achenes are correspondingly as short as $0.6-1.5 \mathrm{~mm}$ and $0.3-0.8 \mathrm{~mm}$. In addition, $C$. compressus is distinguished from taxa such as $C$. difformis in which inflorescences are globular spikes without visible rachises. Also, C. compressus is distinguished from $C$. amuricus and $C$. glomeratus in that the inflorescences are relatively long and spikes loose or somewhat dense. In particular, C. compressus is distinguished from taxa with similar lengths of achenes and scales and very short stalks, such as $C$. amuricus, in that the achenes are only $1 / 2-1 / 3$ of the length of the scales and the stalk is relatively long.

On the other hand, C. compressus is characterized by three stigmas and trigonous achenes; however, this species is distinguished from taxa with two stigmas and biconvex- or plano-convex achenes, such as C. sanguinolentus, C. flavidus, $C$. polystachyos, and $C$. diaphanus and is also treated as a separate genus, Pycreus, depending on the author. In addition, C. compressus is distinguished from culms with only leaf bladeless sheaths at bases such as $C$. papyrus in that there are culms with leaves at the bases; moreover, the number of flowers constituting a spikelet can amount to $10-35$, distinguished from C. cyperoides, which has only 1-3.

The following key to the Korean Cyperus taxa includes Pycreus taxa, treated as separate genera according to some authors, while excluding the genus Kyllinga, which is currently treated as separate genera by most authors as it is characterized by two large scales per spikelet and one to two flowers.

\section{Key to the species of Korean Cyperus, including Pycreus}

1. Stigmas 2, rarely 3 within the same individuals; achenes-biconvex or plano-convex.

2. Achenes laterally compressed, biconvex, angle sides facing the rachillae.

3. Achenes transversely striate on surfaces C. diaphanus 껄끔방동사니

3. Achenes not transversely striate on surfaces.

4. Plants with short creeping rhizomes, ascending at bases and rooted at basal culmnodes C. sanguinolentus 방동사니대가리

4. Plants tufted without rhizomes, erect.

5. Inflorescences simple anthelae with 1-6 primary branches; ultimate spikes somewhat loosely spicate, visible longer rachises; scales broadly elliptic, rounded at apices C. flavidus 드렁방동사니 
5. Inflorescences nearly capitate without primary branches, rarely 1-2 very short branches; ultimate spikes densely capitate, not visible very short rachises; scales narrowly obovate, acute at apices …… C. polystachyos 갯방동사니 2. Achenes dorsiventrally compressed, plano-convex, with flat ventral sides facing the rachillae.

6. Plants more than $50 \mathrm{~cm}$ up to $1 \mathrm{~m}$ tall and with long creeping rhizomes; ultimate spikes loosely spicate, with easily visible long rachises, with longer 4-7 primary branches; achenes widely obovoid or nearly globose

C. serotinus 너도방동사니

6. Plants less than $30 \mathrm{~cm}$ tall, with short creeping rhizomes or absent; ultimate spikes dense capitate-like, with no visible rachises, nearly without primary branches or sometimes 1-2 very short primary branches; achenes narrowly or widely ellipsoid.

7. Achenes with narrow wings at angled margins

C. pacificus 서울방동사니

7. Achenes without wings at angled margins.

8. Stigmas 2, rarely 3 within the same individuals; achenes narrowly ellipsoid, ca. three times longer than wide *. C. pygmaeus 애기방동사니

8. Stigmas 2; achenes widely ellipsoid, ca. two times longer than wide …………… C. nipponicus 푸른방동사니

1. Stigmas 3; achenes trigonous.

9. Plants cultivated for ornamental purposes; culms with only leaf bladeless sheaths at bases; inflorescences with ca. 10-100 primary branches.

10. Culms 1-5 m tall; inflorescences with 30-100 primary branches, arching; involucral leafy bracts 4-10, much shorter than inflorescences; second leafy bracts $2-5$, longer than ultimate spikes; styles much shorter than achenes

C. papyrus 파피루스

10. Culms 0.5-1.5 m tall; inflorescences with 10-20 primary branches, ascending or spreading; involucral leafy bracts 10-20, twice as long as inflorescences; second leafy bracts absent; styles as long as achenes …… C. alternifolius 종려방동사니 9. Plants wild; culms with leaves at bases; inflorescences with ca. 3-10 (-15) primary branches.

11. Rachillae articulate; spikelets with 1-3 flowered, not compressed …………………… C. cyperoides 방동사니아재비

11. Rachillae not articulate; spikelets 3-45 flowered, compressed or nearly so.

12. Ultimate spikes globular capitate, no visible rachises.

13. Annuals; inflorescences with 2-3 leafy bracts; spikelets 3-8 mm long; scales less than $1 \mathrm{~mm}$ long, obovate;

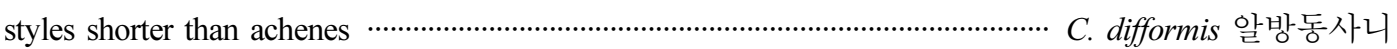

13. Perennials; inflorescences with 4-8 leafy bracts; spikelets 5-20 mm long; scales more than $2 \mathrm{~mm}$ long, ovate; styles nearly as long as achenes ......

C. eragrostis 열 대방동사니

12. Ultimate spikes spicate or digitated, visible rachises or nearly so.

14. Ultimate spikes digitated, with very short rachises or nearly absent; spikelets borne at each rachis apice.

15. Inflorescences usually with only primary branches; scales ca. $3.5 \mathrm{~mm}$, longer; achenes ca. $1.5 \mathrm{~mm}$ long; styles twice as long as achenes

C. compressus 개방동사니

15. Inflorescences with secondary or tertiary branches; scales ca. 0.6-1.5 mm, shorter; achenes ca. 0.3$0.8 \mathrm{~mm}$ long; styles shorter than or nearly equal in length to achenes

16. Perennials with long creeping rhizomes

C. haspan 모기방동사니

16. Annuals without rhizomes.

17. Spikelets ca. $1 \mathrm{~mm}$ wide, reddish brown; scales mucronate at apices; achenes $0.3 \mathrm{~mm}$ long; styles nearly equal in achenes

C. tenuispica 우산방동사니

17. Spikelets ca. 2.0-2.5 mm wide, pale green; scales slightly awned and reflexed at apices; achenes $0.5 \mathrm{~mm}$ long; styles shorter than achenes

C. flaccidus 병아리방동사니

14. Ultimate spikes spicate, with longer rachises; spikelets somewhat densely or loosely throughout rachises.

18. Spikes with somewhat densely spikelets, easily not visible rachises.

19. Scales narrowly oblong, obtuse at apices; achenes narrowly oblong, three times longer than wide *.

C. glomeratus 물방동사니

19. Scales ovate, mucronate at apices; achenes broadly ellipsoid, twice as long as wide $\cdot C$. exaltatus 왕골 18. Spikes with loose spikelets, clearly visible rachises. 
20. Perennials with creeping rhizomes and tubers; styles nearly as long as achenes; achenes much shorter than scales.

21. Rhizomes with globular tubers; inflorescences yellowish, golden or pale brown, with secondary branches; spikes with spreading spikelets; scales somewhat loosely imbricate

21. Rhizomes with ellipsoid tubers; inflorescences reddish brown or purplish brown, with primary branches; spikes with somewhat ascending spikelets; scales densely imbricate

C. rotundus 향부자

20. Annuals; culms tufted without rhizomes; styles distinctly shorter than achenes; achenes nearly as long as scales.

22. Spikes scaberulous hairy at rachises; scales purplish brown, rounded at apices ………… C. orthostachyus 쇠방동사니

22. Spikes without hairs at rachises; scales yellowish or yellowish brown, mucronate to short awned at apices.

23. Inflorescences without secondary branches; scales slightly reflexed awns at apices ……… C. amuricus 방동사니

23. Inflorescences with secondary branches; scales awnless or very short straight awns at apices.

24. Rachises and rachillae narrowly winged; ultimate spikes spreading; scales with very short straight awns at apices … C. microiria 금방동사니

24. Rachises and rachillae nearly wingless; ultimate spikes ascending or appressed to rachises; scales minutely mucronate at apices C. iria 참방동사니

ORCID: Seung Se CHOI https://orcid.org/0000-0002-33325544; Jong Hwan KIM https://orcid.org/0000-0003-02715969; Myoung Jun KIM https://orcid.org/0000-0003-02141029; Chul Hwan KIM https://orcid.org/0000-0003-4894-0651

\section{Acknowledgments}

This work was supported by a grant from the Fifth National Ecosystem Survey of the National Institute of Ecology (NIE) funded by the Ministry of Environment (MOE) of the Republic of Korea (NIE-A-2021-01).

\section{Conflicts of Interest}

The authors declare that there are no conflicts of interest.

\section{Literature Cited}

Bao B. J. and N. J. Tur. 2010. Vicia. In Flora of China 10. Science Press, Beijing and Missouri Botanical Garden Press, St. Louis, MO. Pp. 560-572.

Cho, Y. H., J. H. Kim and S. H. Park. 2016. Grasses and Sedges in South Korea. Geobook Press, Seoul. Pp. 39-287. (in Korean)

Choi, B. H. 2007. Fabaceae. In The Genera of Vascular Plans of Korea. Flora of Korea Editorial Committee (ed.), Academy Publishing Co., Seoul. Pp. 585-622.

Choi, B. H. 2018. Fabaceae. In The Genera of Vascular Plans of Korea. Flora of Korea Editorial Committee (ed.), Hongreung Publishing Co., Seoul. Pp. 770-820.

Chung, T. H. 1957. Viccia. In Korean Flora, Vol. II. Herbarceous Section. Sinjisa, Seoul. Pp. 359-370. (in Korean)

Dai, L. K., G. C. Tucker and D. A. Simpson. 2010. Cyperus. In Flora of China 23. Acoraceae-Cyperaceae. Wu, Z. Y., P. H.
Raven and D. Y. Hong (eds.), Science Press, Beijing and Missouri Botanical Garden Press, St. Louis, MO. Pp 219-241.

Franchet, A. R. and P. A. L. Savatier. 1878. Enumeratio plantarum in Japonia sponte crescentium, Vol. 2. Apud F. Savy, Bibliopolam, Paris. Pp. 324-325.

Govaerts, R. and D. A. Simpson. 2007. World Checklist of Cyperaceae (Sedges). Royal Botanical Gardens, Kew Publishing, Kew, 765 pp.

Han, S., R. Sebastin, X. Wang, K. J. Lee, G.-T. Cho, D. Y. Hyun and J.-W. Chung. 2021. Identification of Vicia Species native to South Korea using molecular and morphological characteristics. Frontiers in Plant Science 12: 608559.

Hoshino, T., T. Masaki and M. Nishimoto. 2011. Illustrated Sedges of Japan. Heibonsha Ltd., Tokyo. Pp. 692-744.

Hosokawa, T. 1933. Notulae Leguminosarum ex Asiae-Orientali. V. Journal of the Society of Tropical Agriculture 5: 287-289

Im, R. J. 1998. Flora Coreana 4. Science and Technology Publishing House, Pyeongyang. Pp. 69-92. (in Korean)

Kern, J. H. 1974. Cyperaceae. In Flora Malesiana, Ser. 1. Vol. 7. Part 3. van Steenis, C. G. G. J. (ed.), Noordhoff International Publishing, Leiden. Pp. 435-753.

Kim C. H and J. H. Park. 2013. Endemic Species of Korea. Plantae. National Institute of Biological Resource, Incheon, 912 pp. (in Korean)

Lee, T. B. 1980. Illustrated Flora of Korea. Hyangmoonsha Publishing Co., Seoul, 990 pp. (in Korean)

Lee, W. T. 1996. Lineamenta Florae Koreae. Academy Publishing Co., Seoul, 1567 pp. (in Korean)

Linnaeus, C. 1753. Cyperus. Pp. 44-47. Species Plantarum, vol. 1. Laurentius Salvius, Stockholm.

Maekawa, F., H. Hara and T. Tuyama. 1961. Makino's New Illustrated Flora of Japan. Hokuryukan Co., Ltd., Tokyo, 1137 pp. (in Japanese) 
Matsumura, J. 1902. A conspectus of the Leguminosae, found growing wild or cultivated in Japan, Loochoo and Formosa. Botanical Magazine, Tokyo 16: 61-86. (in Japanese)

Nakai, T. 1923. Notulae ad plantas Japoniae \& Koreae 29. Botanical Magazine, Tokyo 37: 15-17.

Nakai, T. 1952. A synoptical sketch of Korean flora. Bulletin of the National Science Museum, Tokyo, Japan 31: 1-152.

National Institute of Biological Resources. 2019. National Species list of Korea. I. Plants, Fungi, Algae, Prokaryotes. Designzip, Incheon. Pp. 51-206.

Oh, Y. C. 2000. Cyperaceae in Korea. Sungshin Womens University Press, Seoul. Pp. 121-162.

Oh, Y. C. 2018. Cyperaceae. In The Genera of Vascular Plans of Korea. Flora of Korea Editorial Committee (ed.), Hongreung Publishing Co., Seoul. Pp. 1480-1571.

Ohwi, J. 1984. Leguminosae. In Flora of Japan. Meyer, F. G. and E. H. Walker (eds.), Smithsonian Institution, Washington, DC. Pp. 551-577.

Park, M. K. 1949. Cyperaceae. In An Enumeration of Korean
Plants. Ministry of Education, Seoul. Pp. 292-312. (in Korean).

Park, M. K. 1974. Fabaceae. In Key to the Herbaceous Plants in Korea (Dicotyledoneae). Jeongeumsa, Seoul. Pp. 227-249. (in Korean)

Seok, D.-I. and B.-H. Choi. 1997. Taxonomy study on Viccia unijuga using principal components analysis. Korean Journal of Plant Taxonomy 27: 1-10.

Seok, D.-I. and B.-H. Choi. 1998. Taxonomic relationships in East Asian Vicia species with unijugate leaves based on random amplified polymorphic DNA markers. Journal of Plant Biology 41: 201-207.

Tucker, G. C., B. G. Marcks and J. R. Carter. 2002. Cyperus Linnaeus. In Flora of North America North of Mexico, 23. Flora of North America Editorial Committee (ed.), Oxford University Press, New York. Pp. 141-191.

Yim, M. H. 1983. A Taxonomic study of genus Vicia in Korea. MS thesis, Ewha Womans University, Seoul, Korea, 45 pp. 